NASA Technical Memorandum 106903

AIAA-95-2681

NASA Lewis Research Center's Combustor Test Facilities and Capabilities

Jean Bianco

Lewis Research Center

Cleveland, Ohio

Prepared for the

31st Joint Propulsion Conference and Exhibit

cosponsored by the AIAA, ASME, SAE, and ASEE

San Diego, Californiá, July 10-12, 1995

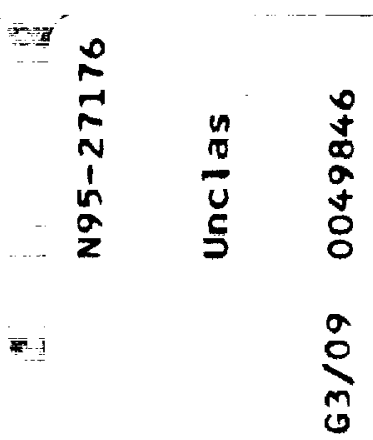

I

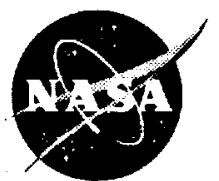

$\pi$

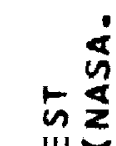

$\omega=$

$n_{\infty} \propto n^{n}$

Iㅁํㅁำ

西出舟

$\checkmark$ 列

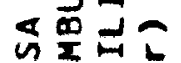

$\frac{1}{2} 00$

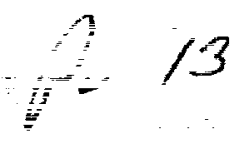


20

$-\cdots+\cdots \cdots$

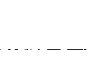

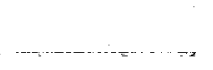

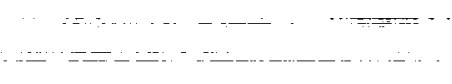

$-$

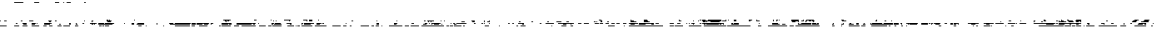

$-\dot{-}---$

-... - -

-

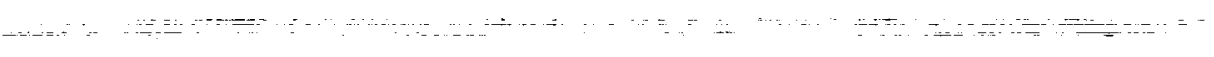




\title{
NASA LEWIS RESEARCH CENTER'S COMBUSTOR TEST FACILITIES AND CAPABILITIES
}

\author{
Jean Bianco \\ Operations Engineer \\ National Aeronautics and Space Administration \\ Lewis Research Center \\ Cleveland, Ohio
}

\begin{abstract}
$\underline{\text { Abstract }}$
NASA Lewis Research Center (LeRC) presently accommodates a number of combustor test facilities with unique capabilities. The facilities are used to evaluate combustor and afterburner concepts for future engine applications, and also to test the survivability and performance of innovative high temperature materials, new instrumentation, and engine components in a realistic jet engine environment. The facilities provide a variety of test section interfaces and lengths to allow for flametube, sector and component testing. The facilities can accommodate a wide range of operating conditions due to differing capabilities in the following areas: inlet air pressure, temperature, and flow; fuel flow rate, pressure, and fuel storage capacity; maximum combustion zone temperature; cooling water flow rate and pressure; types of exhaust-atmospheric or altitude; and types of air heaters-vitiated or nonvitiated. All of the facilities bave provisions for standard gas(emissions) analysis, and a few of the facilities are equipped with specialized gas analysis equipment, smoke and particle size measurement devices, and a variety of laser diagnostic systems. This report presents some of the unique features of each of the combustor test facilities at NASA Lewis.
\end{abstract}

\section{Introduction}

Advanced jet engine development must meet stringent requirements of economical viability and environmental compatibility. One major environmental constraint placed upon the development of advanced combustor concepts is the need for lowered $\mathrm{NO}_{\mathrm{x}}$ emissions levels. Thus, component testing for these advanced combustor concepts will be crucial. In order to stay competitive in the current aerospace market, there is a large demand from U.S. industry for combustor test facilities that can test advanced combustor concepts and associated components at high temperatures and pressures. NASA Lewis presently accommodates a number of combustor test facilities. Six combustor test facilities at the center receive the majority of NASA's in-house combustion support, and these facilities will be highlighted in this report. In two of these facilities, two separate test rigs exist, bringing the total number of combustor test rigs to eight. The various facilities are dispersed throughout the 350-acre main campus of NASA Lewis. One of the facilities, RL-23, is located in the Rocket Lab area of the center; and three of the facilities, CE-5B and CE-9B, and the Advanced Subsonic Combustor Rig(ASCR) are located in the Engine Research Building(ERB). The remaining two facilities, ECRL-1B and ECRL-2A, are housed in the Engine Components Research $\mathrm{Lab}(\mathrm{ECRL})$ building. The facilities can be used for a variety of combustion testing, ranging from low pressure (8.5 ATM) tests at RL-23 to high pressure(60 ATM) tests at ASCR; from small scale flametube tests in CE-5 to large scale component tests in ECRL-1B; from probe gas analysis measurements in CE-9 to nonintrusive laser diagnostic measurements in CE-5; and from fuel injector screening tests in RL-23 to material survivability tests in ECRL-2A. The general capabilities of each of the six combustor test facilities at NASA Lewis will be covered in greater detail in the sections to follow.

\section{Facility Capabilities}

The combustor test facilities at NASA Lewis rely on the center's central equipment services for supply of high pressure air and/or for a simulated altitude exhaust. The high pressure air is provided to each facility by the central air system compressors. The air is filtered to a rating of less than $50 \mu \mathrm{m}$ and the dew point level is maintained between -15 and $-144{ }^{\circ} \mathrm{F}$ by means of dehydrators. All facilities, with the exception of the two ECRL facilities, use a nonvitiated heater to supply the test sections with high temperature air. The air is heated by shell and tube type heat exchangers, using combustor cans fueled with either natural gas or jet fuel. High pressure jet aircraft fuel(Jet $A$ 
or $\mathrm{JP}-5$ ) is available to fuel the combustors in all facilities, with large capacity storage tanks located nearby. In addition, high pressure gaseous hydrogen is currently used in one of the facilities as an alternative test fuel. Hydraulic fluid systems are also used in some of the facilities for operation of fast response control valving. The combustor test rigs exhaust either to the atmosphere or the central altitude exhaust system, which can provide a vacuum of up to 26 in. $\mathrm{Hg}(2$ psia), simulating an altitude exhaust environment. Cooling water, supplied at low, intermediate, and high pressure, is available for quench sprays as well as cooling for any components located near or in the high temperature environment. Gaseous nitrogen is available for use as a purge gas and/or to cool components exposed to the high combustor temperatures. Steam tracing is available for use in line heating of the emission samples to the gas analysis equipment. In addition to those features mentioned above, all facilities are equipped with roof ventilation fans and $\mathrm{CO}_{2}$ room flooding capabilities for prevention and/or response to emergency situations. All of the combustor facilities use computer systems to record, calculate and display results during a typical test run. A computerized data collection system, named ESCORT, is used and allows for steady state data acquisition, one second update rate, and conversion of $\mathrm{mV}$ signals to engineering units. The facilities make use of standard instrumentation such as pressure transducers, thermocouples, strain gauges, and flowmeters. Programmable logic controllers utilize ladder logic to allow the interconnection of permissives, shutdowns, and delay timers for automatic response of various components. In addition, on-line gas analysis of the exhaust gas is performed in all of the facilities, focusing on species such as UHC, $\mathrm{CO}, \mathrm{CO}_{2}, \mathrm{NO}, \mathrm{NO}_{\mathrm{x}}$, and $\mathrm{O}_{2}$. Unique to one or more of the facilities is the ability to take measurements using a smoke meter, particle size analyzer, or gas chromatograph/mass spectrometer(GCMS). Diagnostic measurements can be taken in two of the facilities using an ND:YAG Dye laser system, an Excimer laser system, or an Argon-Ion laser. These measurements focus on the species, temperatures, droplet size, or flow pattems of the combustion process. Each combustor facility at NASA Lewis has unique capabilities and support equipment available for testing and these features are outlined below.

\section{RL-23 Combustor Test Facility}

The RL-23 combustor test facility (Fig. 1) is located in the Rocket Lab area of the center. This high temperature/ low pressure facility is currently used in support of the NASA High Speed Research(HSR) Program focusing on supersonic test conditions, and the NASA Advanced Subsonic Technology(AST) Program focusing on subsonic test conditions. The test rig is currently configured to test a fuel-rich, catalytic reaction experiment, however, it is soon to be converted over to a flametube type rig. The test section configuration is $100 \mathrm{in}$. in length and the interface is a 6 in., 900 LB inlet flange and a 6 in., 150 LB outlet flange. The flametube rig will have a 3 in. square or circular cross-section flowpath which will match the flametube rig in test cell CE-5. This new test rig will be used to evaluate and screen fuel injector concepts prior to testing at the higher pressure facilities. The advantages of using this lower pressure facility are its lower cost and its availability. This facility can, therefore, be used to select the more promising concepts to be tested at the higher demand facilities.

The facility is capable of supplying heated air to the test rig at $125 \mathrm{psig}(8.5 \mathrm{ATM}), 1500^{\circ} \mathrm{F}$ and $2.0 \mathrm{pps}$; and the facility uses a shell and tube heat exchanger to beat the air. The flametube test rig will be operated at $90 \mathrm{psig}$. The hot exhaust air within the combustion zone is limited to $3000^{\circ} \mathrm{F}$ and is quenched with water sprays before venting to the atmosphere. The vitiated air in the heat exchanger, 3.0 pps at $125 \mathrm{psig}$, is heated through the use of a NASA designed, jet fueled burner can to $1650^{\circ} \mathrm{F}$. Two fuel storage tanks, one 600 gallon tank and one 1000 gallon tank, are located at the facility and a maximum flow of $5.5 \mathrm{GPM}$ at 480 psig can be supplied to the test rig. Cooling water, $118 \mathrm{GPM}$ at $115 \mathrm{psig}$, is available for cooling and quenching purposes.

\section{CE-5 Combustor Test Facility}

The CE-5 combustor test facility (Fig. 2), located in the central-east wing of ERB, houses two combustor test rigs, Stand 1 and Stand 2. This high temperature/high pressure facility is currently used for flametube and sector tests for the NASA HSR Program. In addition, flametube tests are conducted for the NASA AST Program. The Stand 1 test rig is a three cup sector rig with an approximate 8 in. $\times 4$ in. flowpath. This test section configuration is $60 \mathrm{in}$. in length and the interface is a 12 in., $300 \mathrm{LB}$ inlet flange and a 12 in., 300 LB outlet flange. The Stand 1 rig hardware and test program are part of a joint venture between NASA and General Electric. The Stand 2 test rig is the flametube rig, capable of either a 3 in. square or circular cross-section flowpath, and is used to evaluate fuel injector concepts. The test section configuration is 51 in. in length and the interface is a 16 in., $400 \mathrm{LB}$ inlet flange and a 12 in., $400 \mathrm{LB}$ outlet flange. In addition, testing can be performed on both rigs using four Quartz windows, located $90^{\circ}$ apart and measuring 1.5 in. $\times 2$ in., for nonintrusive measurements of the combustion zone. The Stand 2 test rig has the added capability of incorporating two Sapphire windows, measuring $2.5 \mathrm{in}$. in diameter, in the mixing or vaporization zone of a lean, premixed/prevaporized type fuel injector. The testing in the facility, although not "classified", is considered "sensitive" in nature and there are protective measures used to maintain the necessary control over 
hardware, data, and facility access. The higher rig pressures, larger rig envelopes and advanced diagnostic measurement capabilities make this facility an attractive one to industry.

A simplified air flow schematic of the test facility is shown in Fig. 3. The facility is capable of supplying heated air to the test rigs at $450 \mathrm{psig}(30 \mathrm{ATM}), 1100{ }^{\circ} \mathrm{F}$ and $20.0 \mathrm{pps}$, although the current test rigs are limited to 300 psig and less than 10.0 pps. The hot exhaust air within the combustion zone is limited to $3200^{\circ} \mathrm{F}$ on both test rigs. This air is quenched and then vented to the altitude exhaust system which can provide a vacuum of up to 26 in. of mercury ( 2 psia). The facility uses a single pass shell and tube heat exchanger to heat up the high pressure air. The vitiated air, $20.0 \mathrm{pps}$ at $40 \mathrm{psig}$, is heated through the use of four J-47 natural gas bumer cans to $1400^{\circ} \mathrm{F}$. Two 600 gallon fuel storage tanks are located at the facility and a maximum flow of $3.0 \mathrm{GPM}$ at 900 psig can be supplied to the test rigs. Cooling water, $60 \mathrm{GPM}$ at 60 psig; $150 \mathrm{GPM}$ at $460 \mathrm{psig} ; 50 \mathrm{GPM}$ at $350 \mathrm{psig}$; and $250 \mathrm{GPM}$ at 395 psig is available for cooling and quenching purposes. High pressure gaseous nitrogen, 0.5 pps at $335 \mathrm{psig}$, is used as film cooling for the Quartz windows when installed in either test rig.

The CE-5 test facility also houses some unique measurement equipment that can be used to further study the combustion process. A smoke meter, particle size analyzer and gas chromatograph/mass spectrometer(GC/MS) are used to further analyze the emissions. In addition, diagnostic measurements can be made using a ND:YAG Dye laser system, an Excimer laser system or an Argon-Ion laser. These further analyze the species, temperatures, droplet size, or flow patterns of the combustion process.

\section{CE-9 Combustor Test Facility}

The CE-9 combustor test facility (Fig. 4), located in the central-east wing of ERB, houses two combustor test rigs, Stand A and Stand B. This high temperature/high pressure facility is used in support of the NASA HSR Program. The Stand A test rig, with a 4 in. $\times 8$ in. cross section flow path, is currently used for a planar reacting shear layer experiment in which hydrogen is used as the test fuel. The test section configuration is 185 in. in length and the interface is a 4 in., 600 LB inlet flange and an 18 in., $300 \mathrm{LB}$ outlet flange. This test rig also incorporates Sapphire or Quartz windows, measuring 4 in. $\times 9$ in., and laser equipment similar to that in CE-5 so that nonintrusive diagnostic measurements can be made. Thus, the test rig provides turbulence-chemistry interaction data for NASA's Computational Fluid Dynamics(CFD) studies. The Stand A rig is soon to be converted over to a rich burn, quick quench lean burn sector rig, which will be a joint venture between NASA and Pratt \& Whitney. The Stand B test rig is used for the Enabling Propulsion Material subtask under
NASA's HSR program. This test, called the ceramic matrix composites experiment, is used to perform cyclic and survivability tests on various ceramic composite materials at combustor operating conditions. The test section configuration is 110 in. in length and the interface is a 12 in., 600 LB inlet flange and a 12 in., 300 LB outlet flange. Four to sixteen ceramic panels, measuring $3.5 \mathrm{in.} \times$ 2 in., 3.5 in. $\times 4$ in., or 3.5 in. $\times 8$ in. and 0.100 to 0.250 in. thick, can be tested simultaneously. The advantages of this facility, as with CE-5, are the higher pressures, larger rig envelopes and diagnostic measurement capabilities. Further, the varied capability of burning hydrogen in place of jet fuel is an added attraction.

A simplified air flow schematic of the test facility is shown in Fig. 5. The facility is capable of supplying beated air to the test rigs at 450 psig ( 30 ATM), $1050^{\circ} \mathrm{F}$ and 15.0 pps. The facility uses a single pass shell and tube heat exchanger to heat up the high pressure air. The vitiated air, 15 pps at 40 psig, is heated through the use of four $\mathrm{J}-47$ natural gas burner cans to $1400{ }^{\circ} \mathrm{F}$. There is a 5000 gallon fuel storage tank at the facility and a maximum flow of $11 \mathrm{GPM}$ at 900 psig can be supplied to either test rig. Cooling water, $175 \mathrm{GPM}$ at $550 \mathrm{psig}, 135 \mathrm{GPM}$ at $835 \mathrm{psig}$ and $42 \mathrm{GPM}$ at $60 \mathrm{psig}$, is available for cooling and quenching purposes.

The Stand A rig is operated by mixing the nonvitiated, heated air with a hydrogen-nitrogen flow mixture which then causes a chemical reaction to take place. This mixture, 0.125 pps hydrogen at $125 \mathrm{psig}$ and $6.0 \mathrm{pps}$ nitrogen at $125 \mathrm{psig}$, is heated to $200^{\circ} \mathrm{F}$ before being mixed with air. A $70000 \mathrm{ft}^{3}$ tuber is located at the facility for the hydrogen supply. The hot air exhaust within the combustion zone is limited to $4000^{\circ} \mathrm{F}$. The air is quenched and then vented to the atmosphere. When the Stand A rig is converted to a sector rig, it will operate at 275 psig with 6 pps air flow available for the lean-burn section and 4 pps air flow available for the rich-burn section. The Stand B rig, on the other hand, is operated at 300 psig and 8.65 pps air flow. The hot air exhaust on this rig is limited to $3500^{\circ} \mathrm{F}$ and after quenching can be vented to either the altitude exhaust system or to the atmoshpere.

\section{ASCR Combustor Test Facility}

The ASCR combustor test facility (Fig. 6), housed in the west wing of ERB, is due to be operational by the end of the 1995 calendar year. This high temperature/high pressure facility will be used to support the NASA AST Program focusing on subsonic test conditions. The first test rig to be installed will be a flametube type rig with varying flowpath capability from a 3 in. ${ }^{2}$ to a 6 in. ${ }^{2}$ cross-section. The test section configuration is $100 \mathrm{in}$. in length and the interface is a 12 in., $900 \mathrm{LB}$ inlet flange and a 20 in., $900 \mathrm{LB}$ outlet flange. The test rig will be used to evaluate 
a number of new and improved fuel injector concepts. This facility is unique in its combination of high pressure, high temperature and high flow capabilities. In addition, the rig envelope is considerably larger than that available in the CE-5 and CE-9 test rigs.

A simplified air flow schematic of the test facility is shown in Fig. 7. The facility is capable of supplying beated air to the test rigs at 900 psig (60 ATM), $1300^{\circ} \mathrm{F}$ and 38.0 pps. The hot air exhaust within the combustion zone will be limited to $3200{ }^{\circ} \mathrm{F}$ and is quenched with water sprays before venting to the atmosphere. The facility uses a shell and tube heat exchanger to heat up the high pressure air. The vitiated air, $50.0 \mathrm{pps}$ at $150 \mathrm{psig}$, is heated through the use of a single J-58 jet fueled combustor can to $1700^{\circ} \mathrm{F}$. A 20000 gallon fuel storage tank is located at the facility and a maximum flow of 2.6 pps at 1500 psig can be supplied to the test rig. Cooling water, $3800 \mathrm{gpm}$ at $60 \mathrm{psig}$; $70 \mathrm{gpm}$ at $335 \mathrm{psig} ; 1200 \mathrm{gpm}$ at $750 \mathrm{psig}$ and $298 \mathrm{gpm}$ at 1500 psig is available for cooling and quenching purposes.

Future plans for the facility include conversion of the flametube test rig to a rich direct injection or sector test rig with diagnostic ports. In addition to this, laser systems and specialty gas analysis equipment such as that currently available at the CE-5 test facility, will be installed.

\section{ECRL-1B Combustor Test Facility}

The ECRL-1B combustor test facility (Fig. 8) is located in the Engine Components Research Lab of NASA Lewis. This high temperature/high pressure facility is currently used to evaluate the survivability of materials at high temperature. The majority of tests in this facility are classified and the facility is currently configured with necessary controls to accept test programs of this type. A unique feature of this facility is the emissions or sampling capability. The facility is equipped with a 9 port, water-cooled gas sampling probe that can traverse the airstream much like a pendulum. Also, a particle size analyzer can be used to measure the number and distribution of particles in the gas stream. The test section configuration is 90 in. in length with 18 in., 300 LB flanges on the inlet and outlet piping.

A simplified air flow schematic of the test facility is shown in Fig. 9. The facility is capable of supplying nonvitiated, heated air to the test rig at 150 psig ( 10 ATM), $100.0 \mathrm{pps}$, and $600^{\circ} \mathrm{F}$; or vitiated, heated air to the test rig at $150 \mathrm{psig}, 50.0 \mathrm{pps}$, and $2000^{\circ} \mathrm{F}$. The hot air exhaust is quenched with water sprays and is vented to either the atmospheric or altitude exhaust. The vitiated air for the heat exchanger, supplied by an air blower at $125000 \mathrm{ft}^{3} / \mathrm{min}$, is heated through thirty-six $\mathrm{J}-47$ combustor cans which are fueled with natural gas. The $600^{\circ} \mathrm{F}$ air can then be fed through a single J-58, jet fueled combustor can which will supply a vitiated hot air exhaust at $2000^{\circ} \mathrm{F}$. Additional fuel can be introduced into the test section, thereby increasing the air temperature op to $3500^{\circ}$. One 5000 gallon, two 10000 gallon and two 20000 gallon fuel storage tanks are located at the facility and a maximum flow of $70.0 \mathrm{GPM}$ at 990 psig can be supplied to both the $\mathrm{J}-58$ burner and the test section. Cooling water, $1200 \mathrm{GPM}$ at $150 \mathrm{psig}$, is available for cooling and quenching purposes.

\section{ECRL-2A Combustor Test Facility}

The ECRL-2A combustor test facility (Fig. 10) is also located in the Engine Components Research Lab of NASA Lewis. This high temperature/high pressure facility is currently used to support the NASA HSR program and to evaluate the survivability of materials and instrumentation in a realistic afterburner environment. The test rig can accommodate two 12 in. $\times 12$ in. material plates for experimentation. The test section configuration is 67.5 in. in length and the interface is a 16 in., 150 LB flange on the inlet and outlet piping. This facility, as in ECRL-1B, has the necessary controls to accept a classified test program.

A simplified air flow schematic of the test facility is shown in Fig. 11. The facility is capable of supplying heated, vitiated air to the test section at $150 \mathrm{psig}$ (10 ATM), $31 \mathrm{pps}$ and 500 to $2500^{\circ} \mathrm{F}$. The hot air exhaust is quenched with water sprays and is vented to either atmospheric or altitude exhaust. A single J-47 combustor can, fueled with either natural gas or jet fuel, is used to obtain temperatures up to $500^{\circ} \mathrm{F}$. The air can then be fed through a jet fueled J-58 combustor can to get to temperatures of 700 to $2500^{\circ} \mathrm{F}$. ECRL-2A shares the ECRL fuel storage tanks listed above and a maximum fuel flow of 10.0 GPM at 600 psig can be supplied to the combustor cans. Cooling water, $600 \mathrm{GPM}$ at $150 \mathrm{psig}$, is available for cooling and quenching purposes.

\section{CONCLUSION}

NASA Lewis has made a major commitment to provide government and industry with modern combustion test facilities. The RL-23, CE-5, CE-9 and ECRL facilities have been operating successfully for years. The ASCR facility is due to come on line by the end of the 1995 calendar year. Each of the six test facilities posess state-of-the-art instrumentation and data systems. In two of these facilities both intrusive and nonintrusive measurement techniques can be used. At present, the facilities support both the NASA subsonic and supersonic research programs. The facilities can be configured to accept both sensitive and classified testing. In addition, each of the facilities has the ability to accommodate either joint venture or sole research programs from private industry. For further information on the facility 
capabilities or for information on the availability of a particular facility for testing, contact the appropriate Facility Manager listed below.

Facility Managers: RL-23; CE-5; CE-9; and ASCR Jeffrey A. Swan, Mail Stop 6-8, (216) 433-5434; ECRL-1B and -2A - Richard L. Barth, Mail Stop 6-8, (216) 433-5686; or Facilities Management Branch Chief - John W. Schaefer, Mail Stop 6-8, (216) 433-3853. Mailing Address: NASA Lewis Research Center, 21000 Brookpark Road, Cleveland, OH 44135.

\section{ACKNOWLEDGEMENTS}

The author wishes to thank Mr. D.D. Hulligan, Mr. C.J. Morgan, Mr. H. Fernandez-Ortiz, Mr. S.A. Nemets, Mr.
R.C. Ehlers, Mr. P.M. Pachlhofer, Mr. J.B. Blankenship, and Mr. D.A. Kocan for their assistance in providing up to date information on the facilities.

\section{REFERENCES}

1. Colantonio, R.O.: High Temperature Test Facility at the NASA Lewis Engine Components Research Laboratory. NASA TM-103143, 1990.

2. Colantonio, R.O., et al.: Advanced Combustor Rig at NASA Lewis Research Center's Engine Components Research Laboratory. NASA TM-4546, 1994.

3. Nemets, S.A.: NASA Lewis Research Center's Preheated Combustor and Materials Test Facility. NASA TM-106676, to be published. 


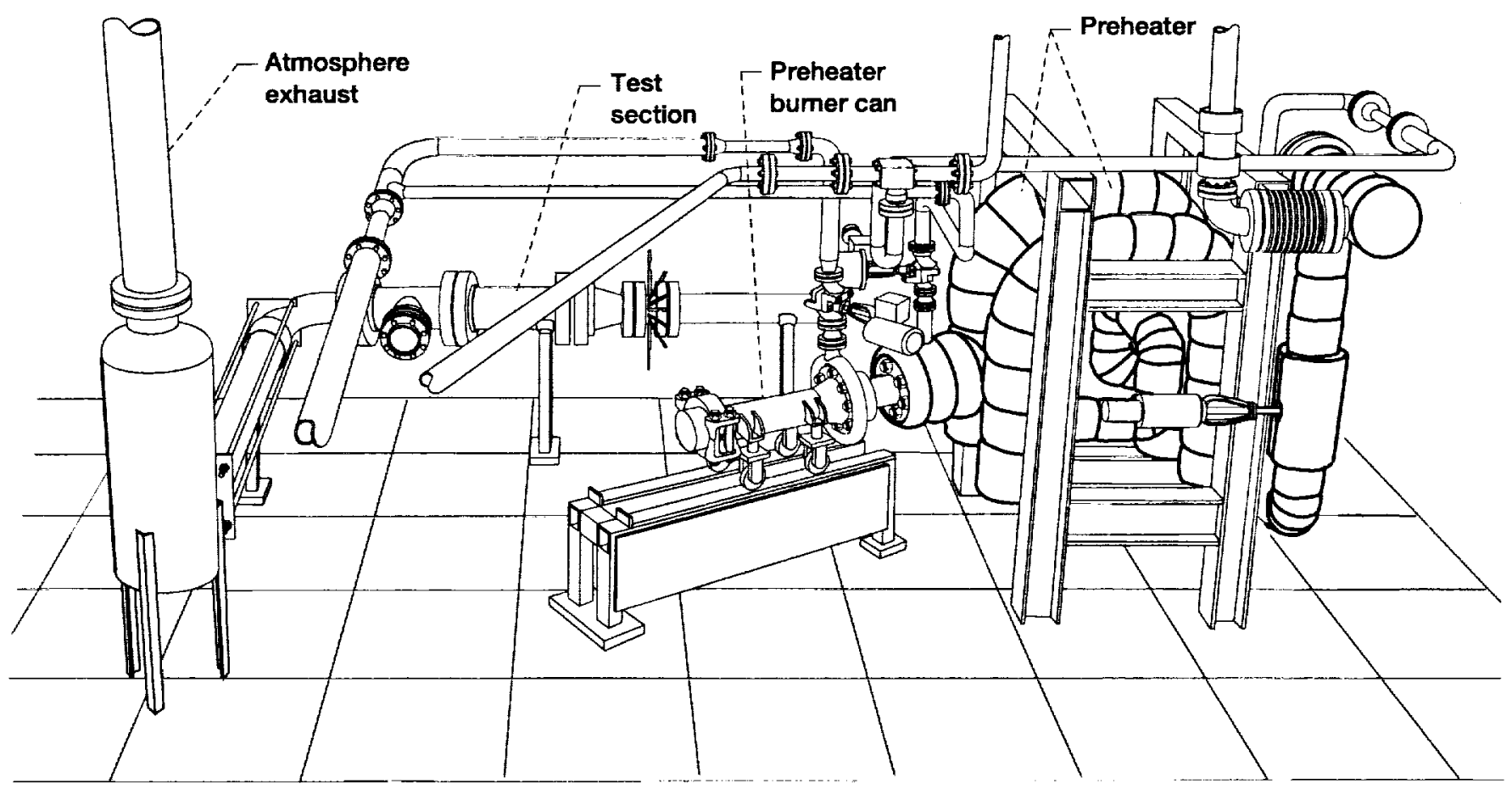

Figure 1.-The RL-23 high temperature/low pressure combustor test facility at NASA LeRC.

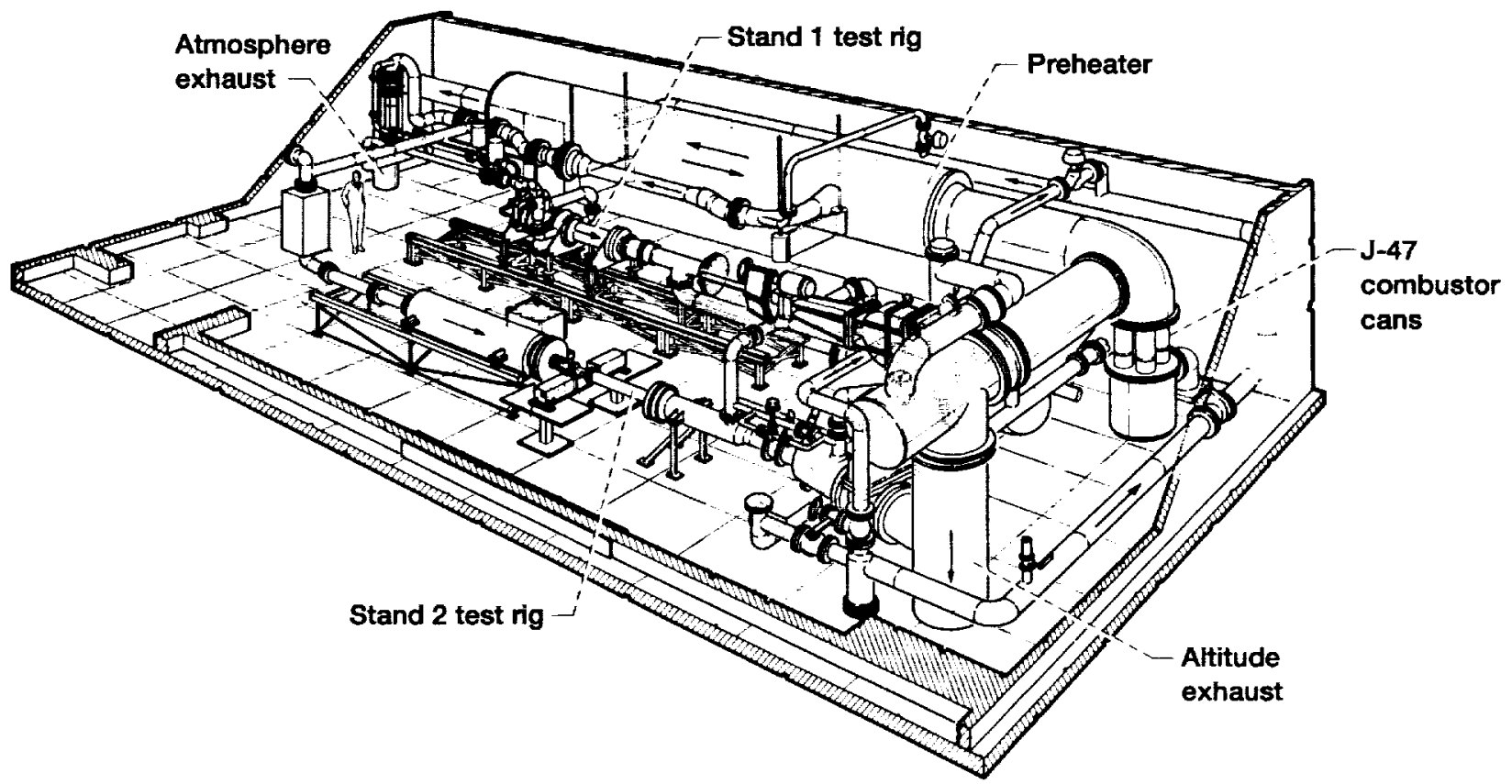

Figure 2.-The CE-5 high temperature/high pressure combustor test facility at NASA LeRC. 


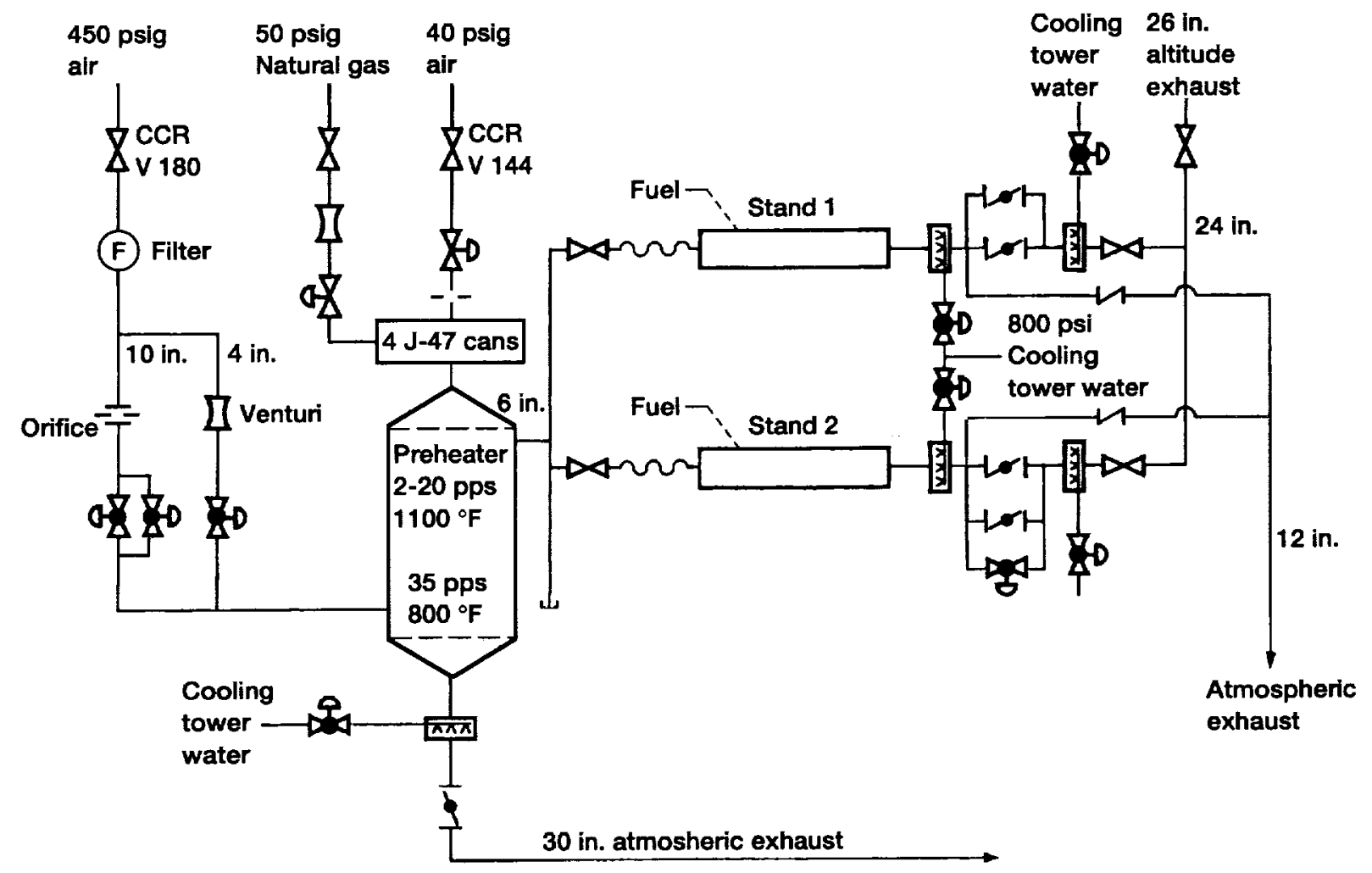

Figure 3.-Airflow schematic of CE-5 combustor test facility.

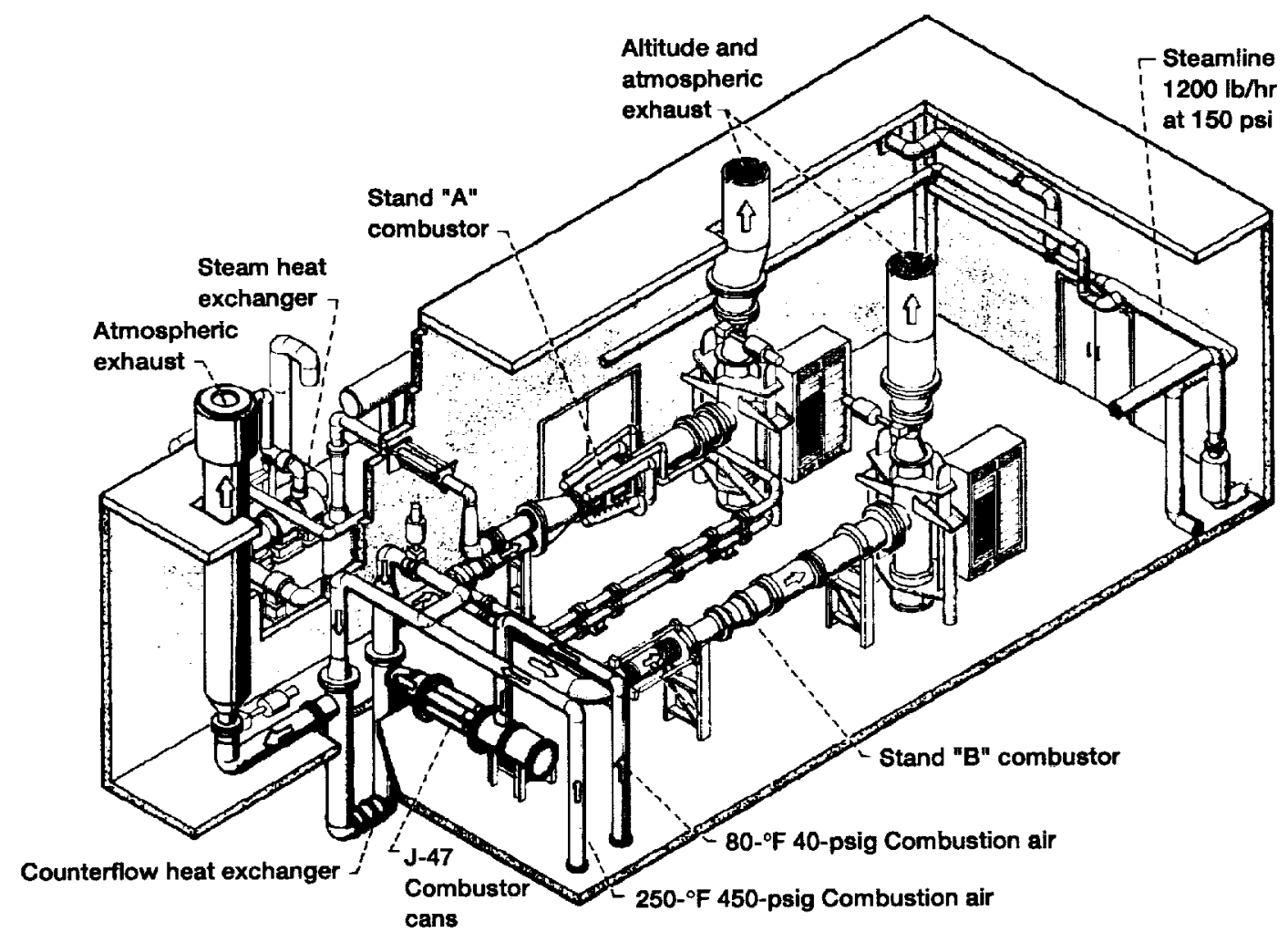

Figure 4.-The CE-9 high temperature/high pressure combustor test facility at NASA LeRC. 


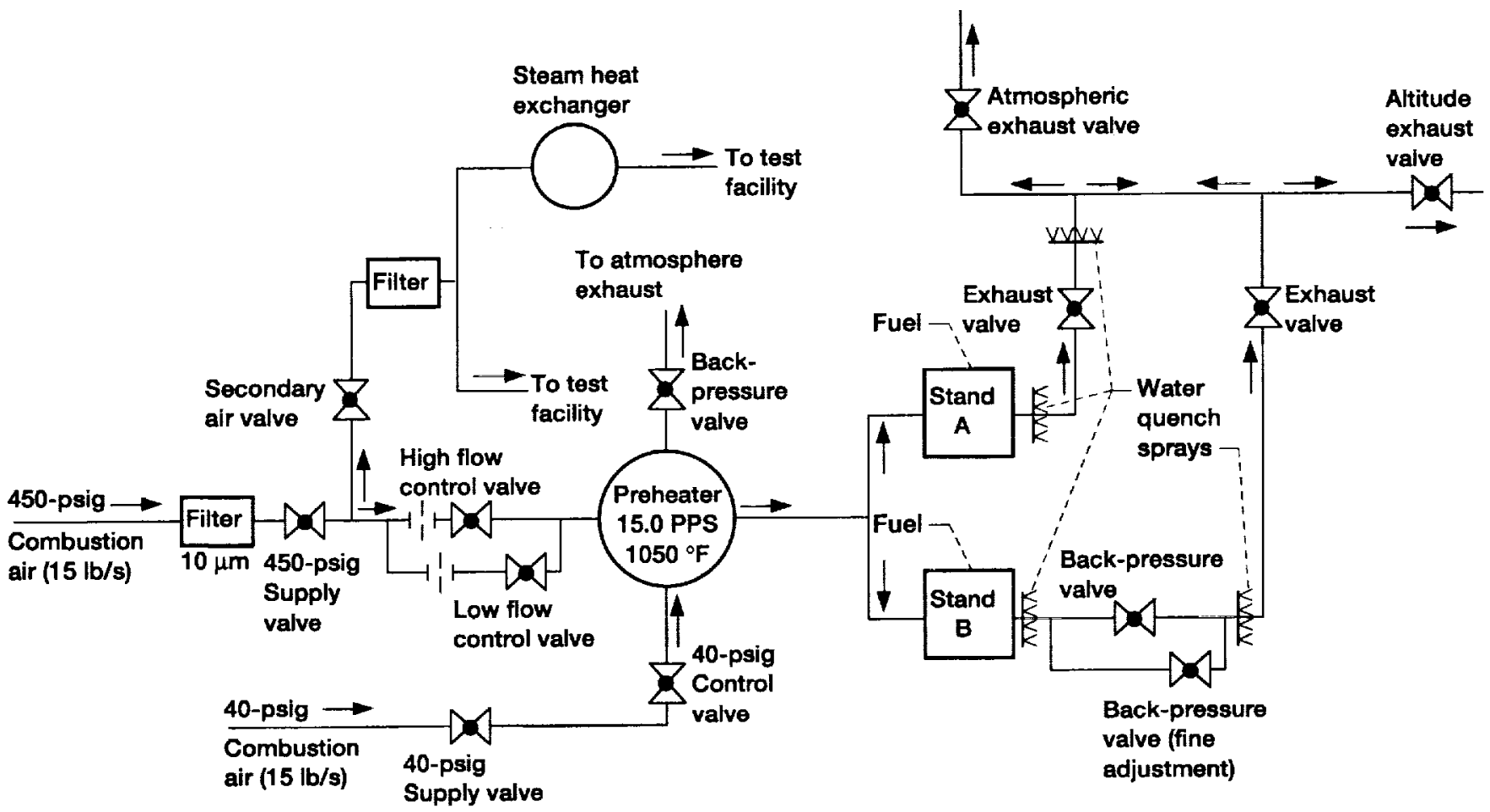

Figure 5.-Air flow schematic of CE-9 combustor test facility.

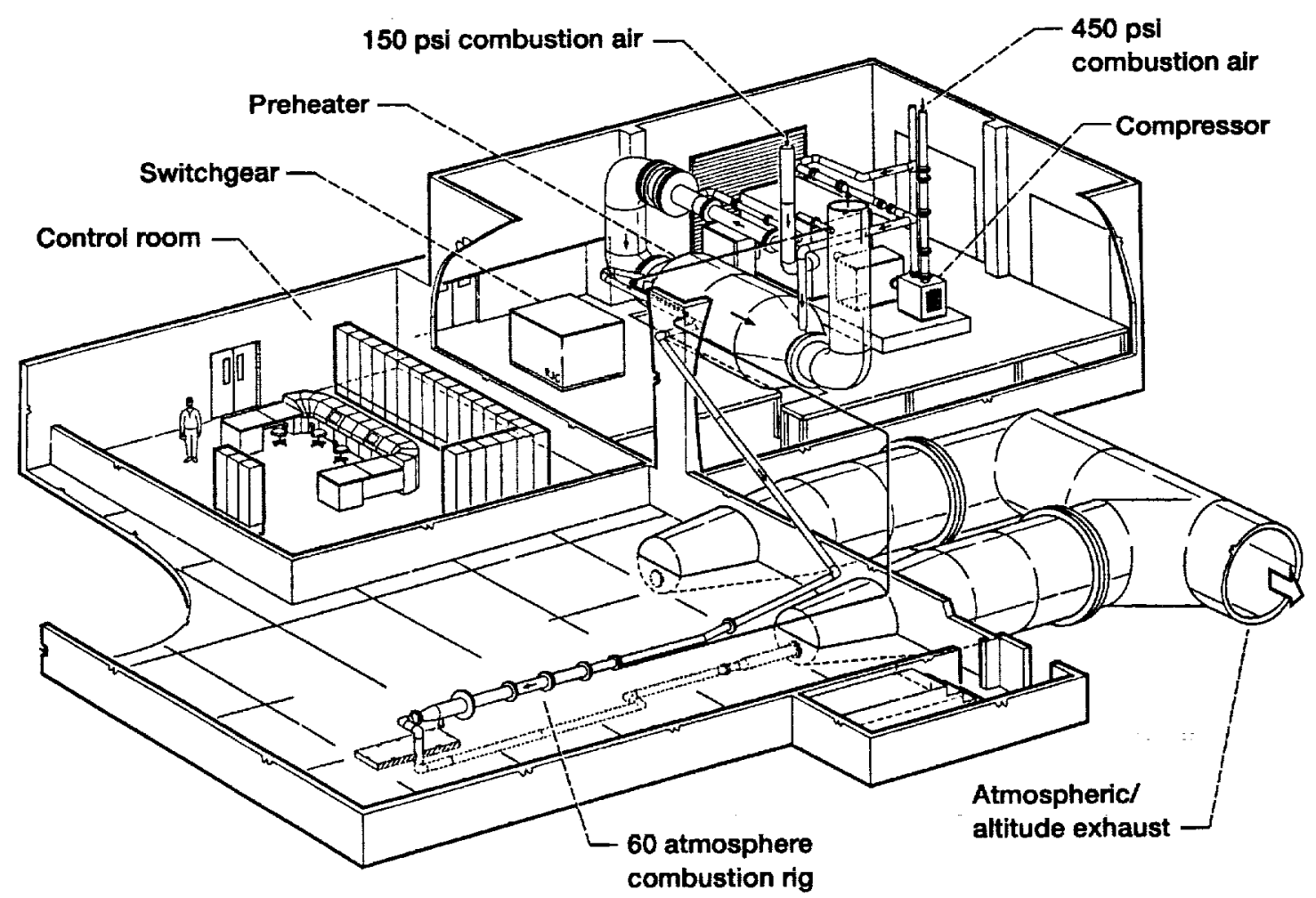

Figure 6.-The ASCR high temperature/high pressure combustor test facility at NASA LeRC. 


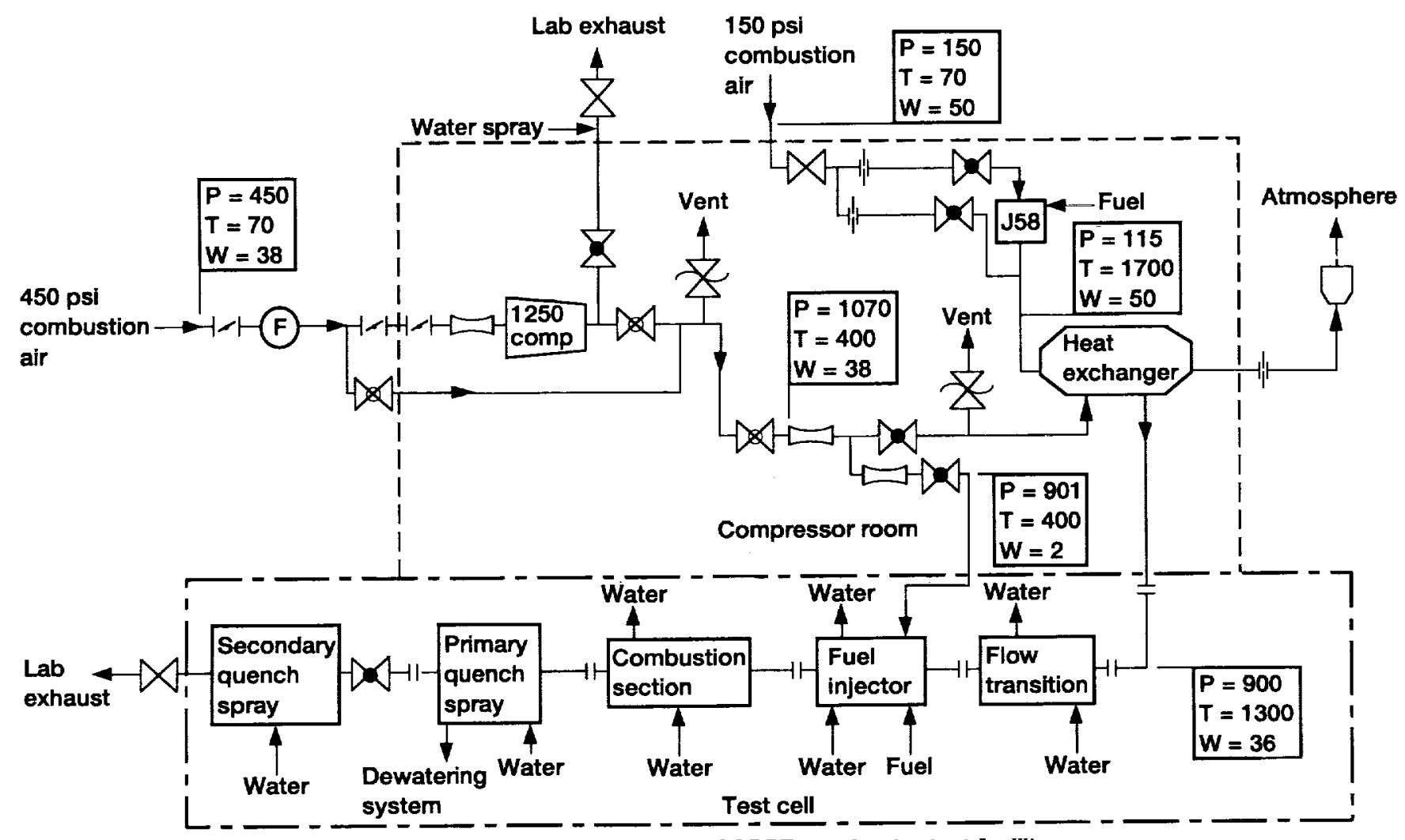

Figure 7.-Airflow schematic of ASCR combustor test facility.

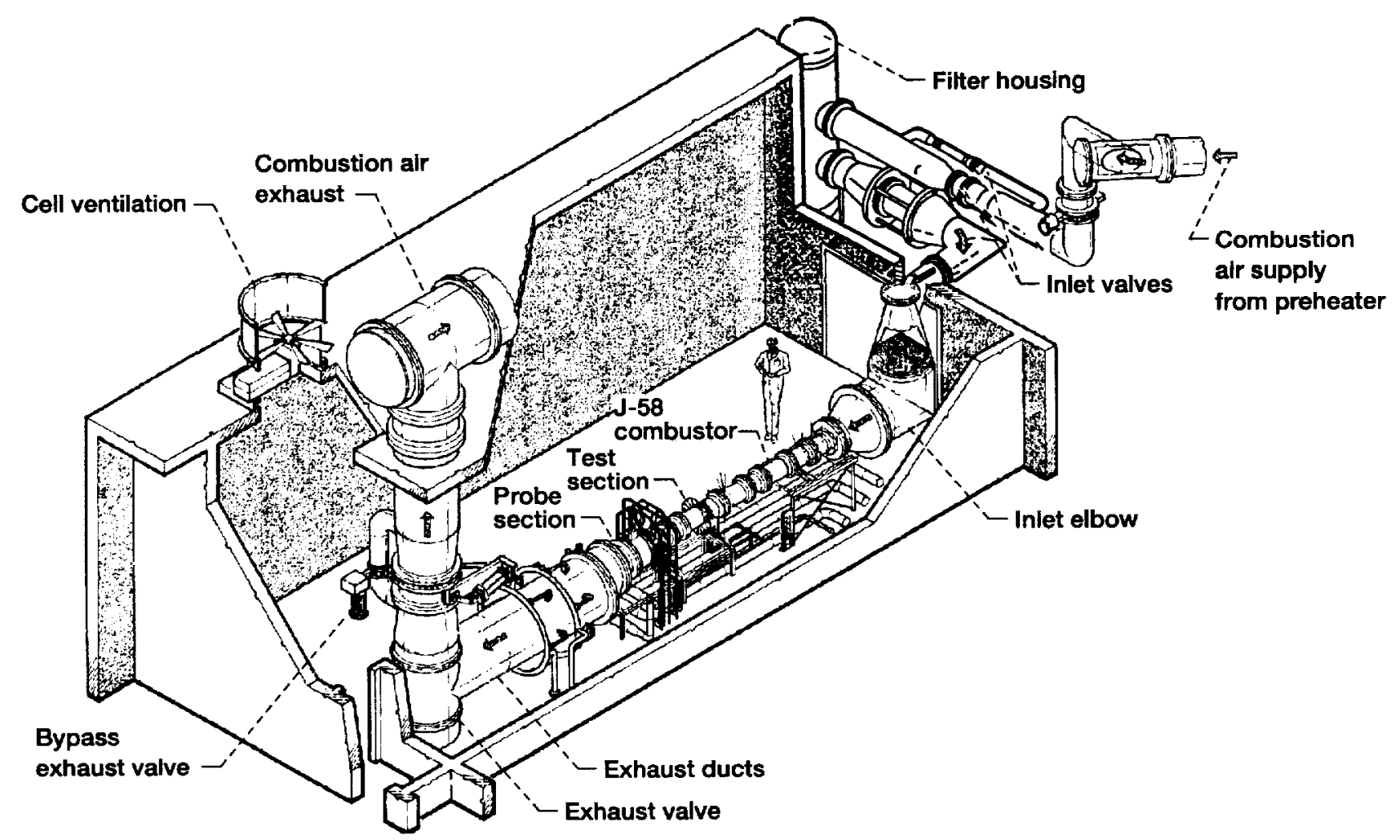

Figure 8.-The ECRL-1B high temperature/high pressure combustor test facility at NASA LeRC. 


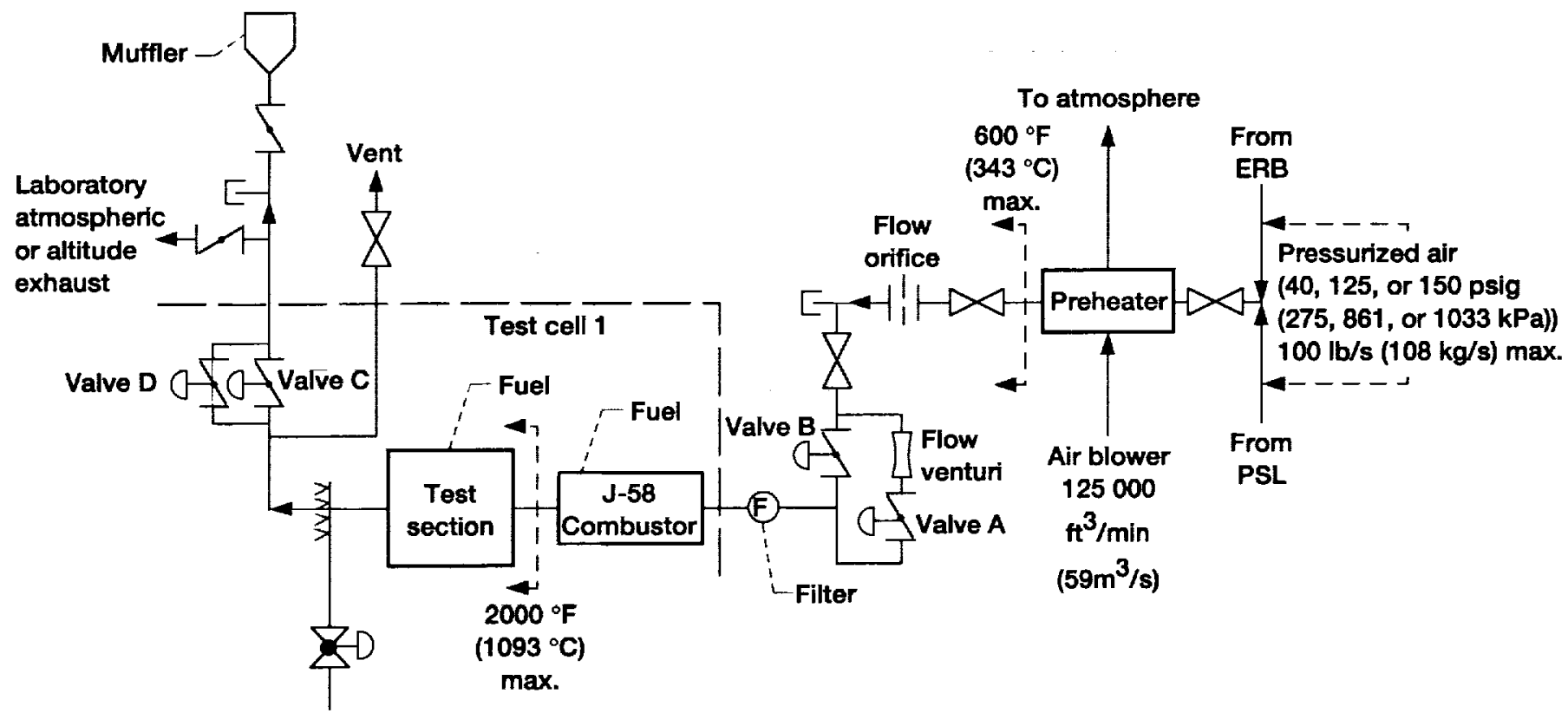

Figure 9.-Air flow schematic of ECRL-1B combustor test facility.

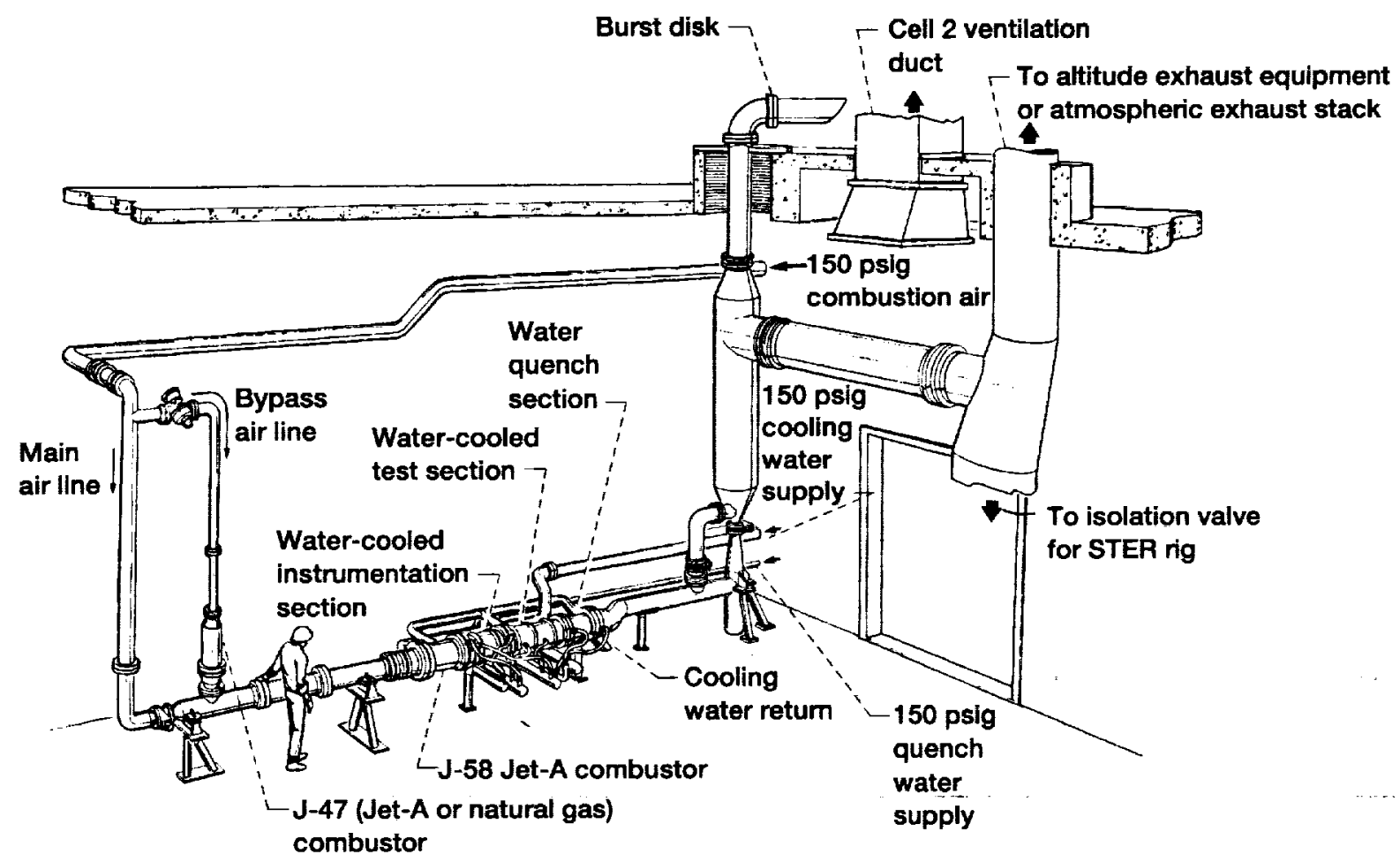

Figure 10.-The ECRL-2A high temperature/high pressure combustor test facility at NASA LeRC. 


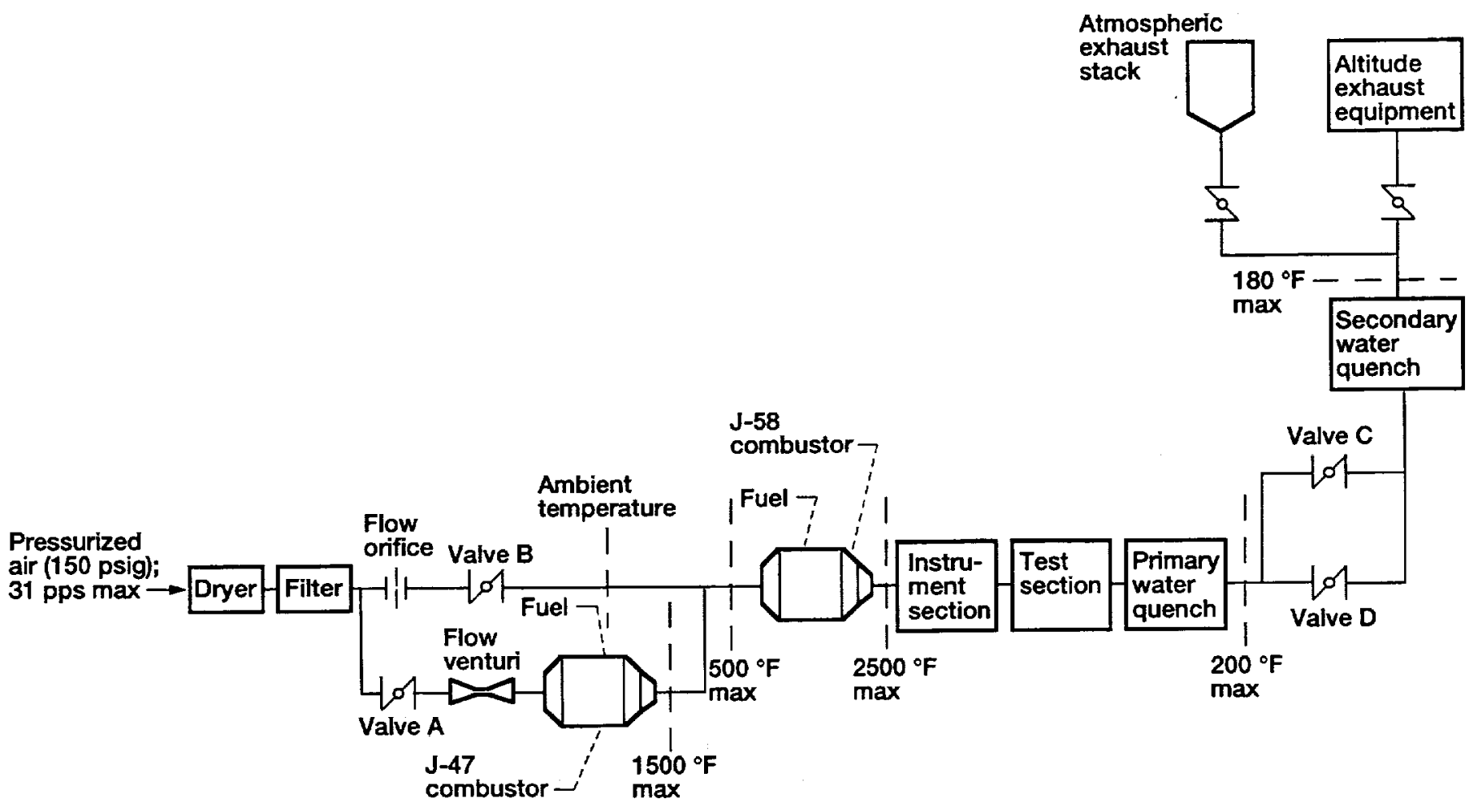

Figure 11.-Air flow schematic of ECRL-2A combustor test facility. 
Public reporting burden for this collection of information is estimated to average 1 hour per response, including the time for reviewing instructions, searching existing data sources, gathering and maintaining the data needed, and completing and reviewing the collection of information. Send comments regarding this burden estimate or any other aspect of this Davis Highway. Suite 1204, Arlington, VA 22202-4302, and to the Office of Management and Budget, Paperwork Reduction Project (0704-0188), Washinglon, DC 20503.

\begin{tabular}{|l|c|c|}
\hline 1. AGENCY USE ONLY (Leave blank) & $\begin{array}{c}\text { 2. REPORT DATE } \\
\text { May } 1995\end{array}$ & $\begin{array}{r}\text { 3. REPORT TYPE AND DATES COVERED } \\
\text { Technical Memorandum }\end{array}$
\end{tabular}

\section{TITLE AND SUBTITLE}

NASA Lewis Research Center's Combustor Test Facilities and Capabilities

6. AUTHOR(S)

Jean Bianco

\section{PERFORMING ORGANIZATION NAME(S) AND ADDRESS(ES)}

National Aeronautics and Space Administration

Lewis Research Center

Cleveland, Ohio 44135-3191

\section{FUNDING NUMBERS}

$$
\text { WU-505-62-82 }
$$

8. PERForming ORgANIZATION REPORT NUMBER

E-9599

9. SPONSORINGMONITORING AGENCY NAME(S) AND ADDRESS(ES)

National Aeronautics and Space Administration

Washington, D.C. 20546-0001

10. SPONSORING/MONITORING AGENCY REPORT NUMBER

NASA TM-106903

AIAA-95-2681

\section{SUPPLEMENTARY NOTES}

Prepared for the 31st Joint Propulsion Conference cosponsored by the AIAA, ASME, SAE, and ASEE, San Diego, California, July 10-12, 1995. Responsible person, Jean Bianco, organization code 2840, (216) 433-8870.

12a. DISTRIBUTIONAVAILABILITY STATEMENT

12b. DISTRIBUTION CODE

Unclassified - Unlimited

Subject Category 09

This publication is available from the NASA Center for Aerospace Information, (301) 621-0390.

13. ABSTRACT (Maximum 200 words)

NASA Lewis Research Center (LERC) presently accommodates a total of six combustor test facilites with unique capabilities. The facilities are used to evaluate combustor and afterburner concepts for future engine applications, and also to test the survivability and performance of innovative high temperature materials, new instrumentation, and engine components in a realistic jet engine environment. The facilities provide a variety of test section interfaces and lengths to allow for flametube, sector and component testing. The facilities can accommodate a wide range of operating conditions due to differing capabilities in the following areas; inlet air pressure, temperature, and flow; fuel flow rate, pressure, and fuel storage capacity; maximum combustion zone temperature; cooling water flow rate and pressure; types of exhaustatmospheric or altitude; air heater supply pressure; and types of air heaters-vitiated or nonvitiated. All of the facilities have provisions for standard gas (emissions) analysis, and a few of the facilities are equipped with specialized gas analysis equipment, smoke and particle size measurement devices, and a variety of laser systems. This report will present some of the unique features of each of the high temperature/high pressure combustor test facilities at NASA LeRC.

14. SUBJECT TERMS

Combustor test facilities; Flows; Pressures; Temperatures; Rig envelopes; Instrumentation; Support equipment

17. SECURITY CLASSIFICATION OF REPORT Unclassified

18. SECURITY CLASSIFICATION
OF THIS PAGE
Unclassified

Unclassified

19. SECURITY CLASSIFCATION
OF ABSTRACT
Unclassified

Standard Form 298 (Rev. 2-89) 


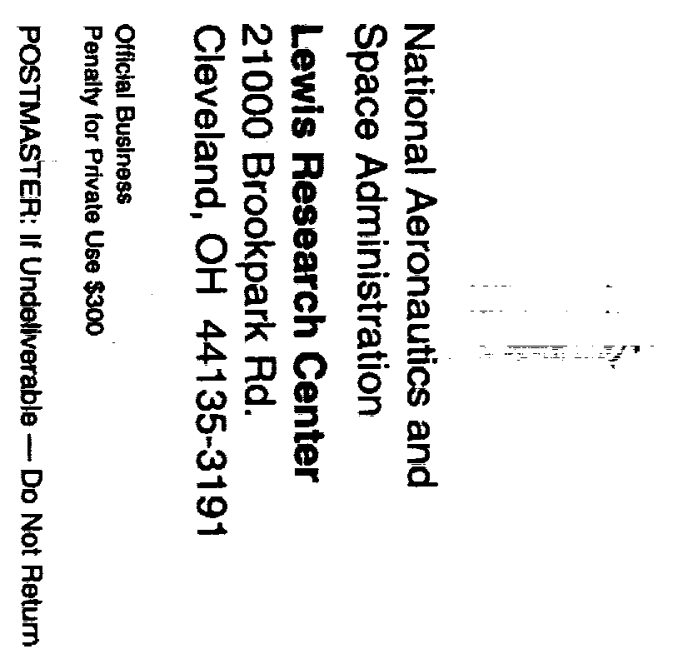

